\title{
The Effect of "Bile" Banana (Musa Paradisiaca) Maturity Level on Microbiological, Chemical and Sensory Quality of Goat's Milk Kefir
}

\author{
Satrijo Saloko $^{1 *}$, Mutia Devi Ariyana ${ }^{1}$, Nadiah Khoiroh ${ }^{1}$ \\ ${ }^{1}$ Faculty of Food Technology and Agroindustry, University of Mataram \\ *Corresponding author. Email: s_saloko@unram.ac.id.
}

\begin{abstract}
Goat's milk is processed into kefir with the hope of eliminating the smell of "strong, goaty odour" and extending the shelf life of goat's milk. Kefir is a probiotic drink whose growth can be optimized with the addition of prebiotics in the form of "Bile" bananas. This study aimed to determine the effect of the maturity level of "Bile" bananas on the microbiological, chemical, and sensory quality of goat's milk kefir. This study used a completely randomized design with one factor (difference in the maturity level of "Bile " bananas : green, yellowish green, yellow, speckled yellow and brown) which repeated 4 times to obtain 20 experimental units. The parameters tested were the degree of acidity $(\mathrm{pH})$, total titrated acid, viscosity, total Lactic Acid Bacteria, viability of Lactic Acid Bacteria and sensory quality including aroma, taste, color and viscosity. The results showed that the maturity level of "Bile" bananas had a significant influenced for all parameters tested. The yellow "Bile" banana maturity level treatment was the best treatment based on $\mathrm{pH}$ value 4.37; total acid number 4.68\%; viscosity 65,750 cP; Lactic Acid Bacteria growth was $8.48 \log \mathrm{CFU} / \mathrm{ml}$ and decreased Lactic Acid Bacteria viability $0.47 \log \mathrm{CFU} / \mathrm{ml}$ as well as sensory properties by scoring and hedonic that can be accepted by the panelists.
\end{abstract}

Keywords: Kefir, Banana, Goat's milk

\section{INTRODUCTION}

Goat milk contains protein that the body needs for cell growth and formation, and is also able to increase durability. The type of goat that produces the most milk is the "Etawa" goat [1]. Goat milk has a nutritional content that is not much different from cow's milk. However, goat's milk has several advantages including the number of small diameter and homogeneous fat granules that are more abundant in goat's milk, so that goat's milk is more easily digested by the human digestive system and does not cause diarrhea in people who consume it [2]. Another advantage of goat's milk is its lactose content which is much lower than cow's milk, thereby reducing the risk of lactose intolerance [3].

Although the nutritional quality of goat's milk is considered superior to cow's milk, so far it has not been favored because of goaty flavor which comes from short and medium chain fatty acids such as caproic acid, caprylic acid and capric acid [4]. In addition, fresh goat's milk is easily damaged. Goat milk can only last at a maximum of 2 hour time under normal circumstances [5].
According to this, it is therefore necessary to eliminate the smell in goat's milk to extend its shelf life without reducing the nutritional value. One of the efforts that can be done is to process the goat's milk into kefir.

Kefir is a beverage product obtained through the fermentation process of pasteurized milk using a starter from a collection of bacteria, including Streptococcus sp., Lactobacilli and several types of non-pathogenic or yeast. This beverage product can have a positive effect on health because it contains microbes that can inhibit the growth of gram-positive and gram-negative pathogenic bacteria, and when regularly consumed, it can maintain the balance of intestinal microbes and stimulate gastrointestinal peristalsis [6]. Microbes that can have an impact as described above are probiotics. Probiotics are dietary supplements in the form of live microbes that provide beneficial effects and improve the balance of the digestive tract in humans [7]. Types of probiotics found in kefir are various groups of lactic acid bacteria such as Lactobacilli, Lactococcus, Lactobacillus kefir, Lactobacillus parakefir, Lactobacillus kefiranofaciens, 
Lactobacillus kefirgranum, yeast and acetic acid bacteria [8].

Probiotics work optimally when assisted by the presence of prebiotics as a source of nutrition and stimulate their growth. Prebiotics are components of food that cannot be digested and have a good effect by triggering activity, selective growth of probiotic bacteria [9]. One of the natural sources of prebiotics is bananas. Banana (Musa sp.) has a high sugar content in the form of inulin and fructo oligosaccharide compounds which act as natural prebiotics [10]. According to Praja [11], bananas contain inulin compounds around $1 \mathrm{~g} / 100 \mathrm{~g}$ of inulin consisting of glucose, fructose, sucrose, and oligosaccharides. Based on the research of Kusharto and Clara [12] bananas contain fructose oligosaccharide (oligofructose) compounds of $0.3 \%$ which are a source of prebiotics to support the growth or activity of probiotic bacteria and can improve body health.

Based on the research of [13], there is an effect of adding prebiotics to the number of bacteria Lactobacillus casei. The presence of prebiotic compounds inulin and fructose oligosaccharides in "kapok" banana flour is useful as a nutrient for probiotic bacteria so that it can increase the growth activity of Lactobacillus casei bacteria. Lactobacillus casei bacteria can break down polysaccharide into galactose, glucose, and fructose which are used as growth nutrients, so that with the addition of "Kapok" banana flour the number of Lactobacillus casei bacteria increases.

One type of banana is the "Bile" banana. "Bile" banana is a typical Lombok banana originating from Sambelia District, East Lombok Regency. This banana is believed to have a long shelf life. "Bile" Bananas have a sweet taste and orange flesh. "Bile" [14] bananas have long fruit stalks and rounded fruit tips. The addition of "Bile" bananas as prebiotics into fermented milk kefir products is carried out in the form of puree based on the level of maturity. The maturity level of "Bile" bananas can be seen from the colour of the skin of the fruit: green, yellowish green, yellow, spotted yellow and brown [15]. Puree is fruit flesh that was mashed and did not go through a dilution process [16]. The addition of "Bile" banana puree as a natural source of prebiotics has the potential to increase probiotic microbial activity in the fermented milk kefir.

The addition of banana "Bile" puree based on the level of maturity has the potential to affect the metabolic activity of probiotic bacteria in goat milk kefir products. This is because the level of banana ripeness can affect the levels of prebiotics contained. In the banana ripening process there is a process of starch hydrolysis into glucose. Starch is a candidate for prebiotics [17]. Based on the research of [18] through the results of the variance, it shows that the level of banana maturity has a significant effect on the starch content of the banana flour produced. The riper the bananas used, the lower the starch content and the higher the sugar content in the banana. This is because the more ripe the fruit, the more starch is hydrolysed into sugar, which is indicated by the sweeter taste.

The addition of banana "Bile" puree based on the level of maturity also has the potential to affect the viability of lactic acid bacteria. This is because bananas contain prebiotic compounds that are able to pass through the upper digestive tract and reach the large intestine, so that they can become one of the nutrients and increase the activity of probiotic bacteria [10]. In addition, maturity level can affect the amount of prebiotic compounds in bananas. Based on the research by [19], banana flour prebiotics resulted in a high viability of lactic acid bacteria and low acidity. This can be proven by the results of research showing that the number of lactic acid bacteria from banana flour prebiotic treatment is 11.37 $\log \mathrm{CFU} / \mathrm{ml}$ when compared to the average number of lactic acid bacteria in probiotic yogurt, which is $10.32 \mathrm{log}$ $\mathrm{CFU} / \mathrm{ml}$. The results of the above study indicate that the presence of inulin and fructose oligosaccharide compounds contained in bananas have the potential to become a source of prebiotics and support the growth of probiotic bacteria. Based on this, a research was conducted on "The Effect of Maturity Level of "Bile" Banana (Musa paradisiaca) on Microbiological, Chemical and Sensory Properties of Goat Milk Kefir".

\section{MATERIALS AND METHOD}

The materials used in this study were "Bile" banana (Sugian Village, Sambelia District, East Lombok), kefir grains (Food Microbiology Laboratory, IPB University, Indonesia), Goat milk used is goat's milk which is still fresh because the freshness of goat's milk only lasts up to 2 hours after milking (UD Muda Bakti Barokah, Kelebuh Village, Central Praya, Central Lombok), water (Aqua, Indonesia), distilled water, buffer solution, de Mann Rogosa Sharpe Agar (MRSA) media (Merck, Germany), de Mann Rogosa Sharpe Broth (MRSB) (Merck, Germany), 70\% alcohol (Medika, Indonesia), $\mathrm{NaCl}$ solution, $0.1 \mathrm{~N} \mathrm{NaOH}$, Bile salt, methanol, and phenolphthalein indicator (PP).

This The equipment used in this study were blender (Philips, Netherlands), filter cloth, analytical balance (Kern, United States), measuring cup, bottle, erlenmeyer, measuring flask, beaker, water bath (Memmert, Germany), label paper, glass plastic, autoclave (Hirayama, Japan), test tube, test tube rack, petri dish, colony counter (Boeco, Germany), knife, hot plate, vortex (Heidolph, Germany), laminar air flow (Streamline, South Korea), glass sample, tissue, rubber band, aluminum foil, stove, steamer pot, statif, biuret, volumetric pipette, rubber bulb, micro pipette, blue tip, yellow tip, bunsen lamp, incubator, $\mathrm{pH}$ meter, magnetic 
stirrer, refrigerator, digital orbital shaker, pycnometer and Ostwalt pipe.

\subsection{Method}

The method used in this study is an experimental method carried out in the laboratory. The experimental design used was a completely randomized design with one factor and five treatments: the maturity level of green "Bile" bananas, yellowish green, yellow, spotted yellow and brown bananas which were repeated 4 times to obtain 20 experimental units. Observational data were analyzed by analysis of variance at a significance level of 5\% using the Costat software Version 22. If there is a significant difference, the data is further tested with a further test of Honest Significant Difference (HSD) for all parameters.

\subsection{Research Implementation}

\subsubsection{Making “Bile” Banana Puree}

According to [20], the bananas chosen as raw materials are "Bile" bananas. "Bile" bananas have a high sugar content which is a prebiotic that bacteria need as a substrate. The process of making "Bile" banana puree is to prepare several bananas according to their level of maturity, wash, peel and steam blanch at $100{ }^{\circ} \mathrm{C}$ for 7 minutes, then cut it into small pieces of about $1 \mathrm{~cm}$ then crush with a blender.

\subsubsection{Rejuvenating Kefir Grain}

Kefir seed propagation and activation refers to the research method of [21]. The process involved adding pasteurized milk into a container containing kefir grains. Incubation was carried out for 24 hours at room temperature of $25^{\circ} \mathrm{C} \pm 3{ }^{\circ} \mathrm{C}$. Next, the kefir grains are separated from the kefir liquid.

\subsubsection{Making Goat Milk Kefir}

The process of making goat's milk kefir is a development and modification of the procedure carried out by [22]. The procedure for making goat's milk kefir begins with the preparation of goat's milk raw materials. Goat milk used is goat's milk which is still fresh because the freshness of goat's milk only lasts up to 2 hours after milking. Furthermore, goat's milk is pasteurized to extend the shelf life for 15 minutes, then cooling, mixing kefir seeds with "Bile" banana puree, fermentation at room temperature for 24 hours, filtering, then the filtered filtrate is put into a bottle, then cooled, then cooled at room temperature $5^{\circ} \mathrm{C}$ to extended shelf life.

\subsubsection{Observation Parameter}

Parameters observed included total lactic acid bacteria test, probiotic viability, total acid number, $\mathrm{pH}$, viscosity test and organoleptic test using 25 semi trained panelists which included aroma, taste, colour and viscosity.

\section{RESULTS AND DISCUSSION}

\subsection{Total Lactic Acid Bacteria}

The addition of "Bile" bananas based on the level of maturity gave an increase in total LAB on goat milk kefir. The graph of the relationship between the addition of "Bile" bananas based on the maturity level of goat milk kefir on total LAB can be seen in Figure 1.

Figure 1 shows that the total LAB in goat's milk kefir decreased with the higher maturity level of "Bile" bananas used. This is due to the different prebiotic content in "Bile" bananas at each level of maturity affecting the total LAB in goat's milk kefir, where in the study of [23] showed that the lower the maturity level of banana flour, the higher the starch content which is a prebiotic in bananas. Prebiotics in bananas are inulin and fructose oligosaccharides [10]. According to [24] kefir grains contain more than 35 types of probiotic bacteria, so that inulin and fructose oligosaccharides in "Bile" bananas can be used to increase total LAB. This is in line with the research results of [25] that fructose oligosaccharides and inulin found in starch and crude fiber in bananas can be used as prebiotics because they can be utilized by LAB for metabolism. In the study of[26] where the increase in total LAB in probiotic ice cream occurred due to the high crude fibre and starch content in banana peel flour so that Lactobacillus casei could be used to grow. The same thing was also found in the research of [27] where the activity of lactic acid bacteria increased with the addition of banana peel flour which showed the role of fructose oligosaccharides used by Lactobacillus acidophilus as a source of nutrition.

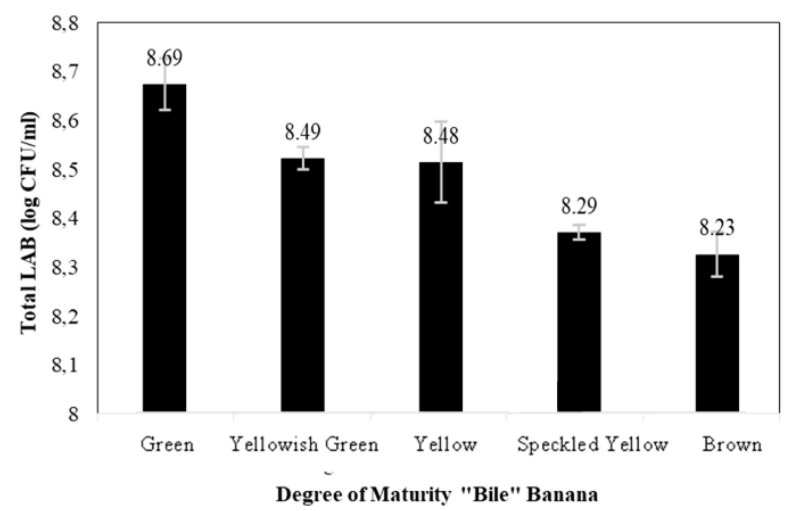

Figure 1 Graph of the Effect of "Bile" Banana Maturity Level on Total Lactic Acid Bacteria 
The more nutrients in the substrate, the faster cell growth, thus the number of lactic acid bacteria cells produced is increasing, resulting in an increase in total LAB. The increase in total lactic acid bacteria with the lower level of maturity of "Bile" bananas added was due to the presence of prebiotics contained in "Bile" bananas in the form of $0.3 \%$ fructose oligosaccharides and $2.1 \%$ inulin contained in starch and fibre. Prebiotics are a source of nutrition for lactic acid bacteria [28]. The amount of prebiotic content in bananas is determined by the level of maturity [29] The higher the maturity level of bananas, the prebiotic content contained will decrease [18]. This is caused by the hydrolysis of starch into sugar by heat, acids or enzymes [29]. The total lactic acid bacteria in goat's milk kefir decreased along with the increase in the level of ripeness of banana "Bile" added. This is in accordance with the statement of [19] that the activity and number of lactic acid bacteria will increase in the presence of prebiotics. [30]said that oligosaccharides can be used as prebiotics because they can be utilized by LAB for metabolism. Based on the results of the study showed that the total $\mathrm{LAB}$ obtained with the addition of banana puree "Bile" based on the level of maturity with the results of 8.23-8.69 $\log$ CFU/ml which indicated that all treatments had met the requirements of SNI 2981-2009 and CODEX Stan 2432003, i.e. a minimum of 107 or $7 \log \mathrm{CFU} / \mathrm{ml}$.

\subsection{Lactic Acid Bacteria Viability}

The LAB viability of goat milk kefir was measured by calculating the LAB survival in "Bile" salts. Samples of goat's milk kefir were contacted with ox gall as an imitation of "Bile" salts. The addition of "Bile" bananas based on the level of maturity gave an effect on the viability of LAB on goat's milk kefir where the effect was in the form of a decrease in total LAB along with the incubation time for all treatments. The graph of the relationship of the effect of adding "Bile" bananas based on the maturity level to total LAB can be seen in Figure 2.

The decrease in cell viability during the incubation period was caused by changes in cellular permeability and leakage of intracellular material in lactic acid bacteria, causing cell rupture and death due to exposure to "Bile" salts for 4 hours [31]. Overall, the addition of raw Bile banana puree resulted in a better reduction in LAB viability on goat's milk kefir than the addition of ripe "Bile" banana puree. This is because the addition of "Bile" banana as a source of prebiotics can maintain the viability of LAB.

This statement is in accordance with [32] who said that the presence of prebiotic components in food can maintain or increase the viability of probiotics while in the gastrointestinal tract. The prebiotic inulin in "Bile" bananas can increase the growth of probiotics by lowering intestinal $\mathrm{pH}$ to an optimal level which is influenced by the physicochemical properties of Bile salts. High concentrations of prebiotic inulin can also reduce the solubility of Bile salts so that it can reduce levels of toxicity to LAB [33]. The amount of prebiotic content contained in bananas will decrease as the level of maturity of bananas increases. According to [34] bananas with green skin colour had $20 \%$ starch while bananas with yellow skin with brown spots only had $1.5 \%$ starch. Where starch acts as a prebiotic that can stimulate the growth of probiotics [35]. So that the treatment with the addition of raw "Bile" bananas had better LAB viability than the addition of ripe "Bile" bananas.

The standard for decreasing the viability of good bacteria is a decrease in total LAB which is not more than $3 \log$ CFU/ml [36]. The results showed that the decrease in $\mathrm{LAB}$ viability in all treatments was not more than $3 \mathrm{log}$ $\mathrm{CFU} / \mathrm{ml}$. This indicates that the addition of banana "Bile" with various levels of maturity to goat's milk kefir can increase the viability of lactic acid bacteria. This is in line with previous research by [37] where symbiotic yogurt with the addition of prebiotics in the form of $2 \%$ inulin can increase the viability of probiotics. Similar results were also shown in previous studies by [27] showing that the addition of banana peel flour to goat's milk kefir provides high probiotic viability. According to [38] the requirement for probiotic drinks contains more than $10^{8}$ or $8 \operatorname{logs}$ of probiotic bacterial cells per millilitre in a live state. Therefore, goat's milk kefir with the addition of banana "Bile" which is a probiotic drink that meets the requirements is banana "Bile" goat's milk kefir with green, yellowish green, yellow and spotted yellow maturity levels. Meanwhile, the addition of "Bile" banana puree with the highest maturity level, namely chocolate, did not meet the requirements because the prebiotic viability value was less than $8 \log \mathrm{CFU} / \mathrm{ml}$.

\subsection{Total Acid Number (TAN)}

Treatment level of ripe banana "Bile" gave a significantly different effect on the total acid number goat milk kefir. The graph of the relationship between the addition of "Bile" bananas based on the level of maturity to the total acid number can be seen in Figure 3.

Figure 3 shows that the higher the maturity level of "Bile" bananas added to goat's milk kefir, the lower the total acid number (TAN) expressed as total lactic acid of goat's milk kefir produced. The increase in TAN expressed as total lactic acid in goat milk kefir in this study was due to the increased growth of lactic acid bacteria (LAB) in goat milk kefir with the addition of banana "Bile" puree. Where in this study the total acid number produced was in line with the total LAB produced, namely the higher the maturity level of "Bile" bananas, the total titrated acid and total LAB would decrease. This result is in line with previous research by[33] which shows that symbiotic yogurt has a value of 


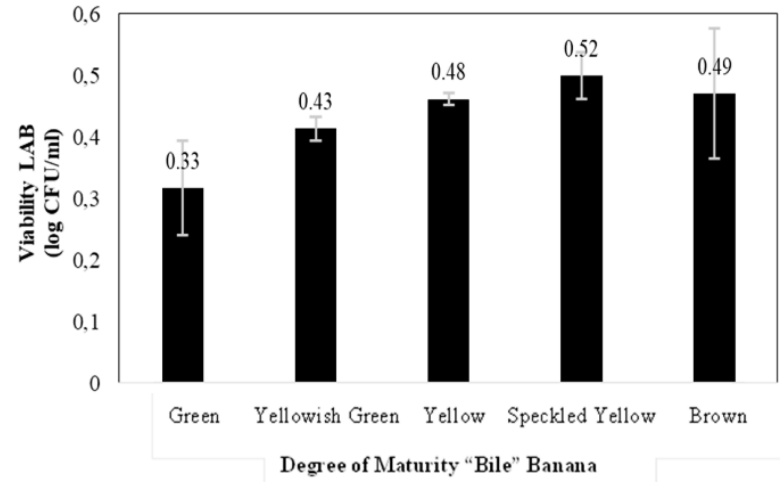

Figure 2 Graph of the Effect of "Bile" Banana Maturity Level on the Viability of Lactic Acid Bacteria (LAB) in "Bile" Salt

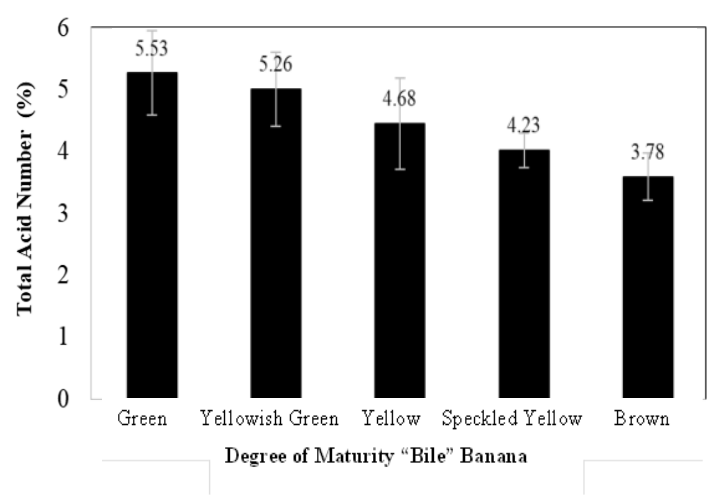

Figure 3 Graph of the Effect of "Bile” Banana Maturity Level on Total Acid Number Goat Milk Kefir

total acid number which is directly proportional to Total LAB. This is because the prebiotics in "Bile" bananas are a supporting medium for the growth of lactic acid bacteria $(\mathrm{LAB})$ on kefir. The lower the level of ripeness of bananas, the higher the prebiotic content, causing higher LAB growth. This results in higher bacterial activity in breaking down lactose into lactate, resulting in an increase in the total acid number expressed as total lactic acid. [39] showed the results where the highest levels of lactic acid were produced in probiotic yogurt with the addition of the highest prebiotic source. During the fermentation process of goat's milk kefir, banana "Bile" which acts as a natural source of prebiotics will facilitate bacteria that will convert lactose (milk sugar) into lactic acid [40].

Another factor that causes the total reduction of lactic acid in goat's milk kefir is the sugar content in banana "Bile" puree which is added to goat's milk kefir. The sugar content in banana "Bile" puree will be higher along with the higher level of maturity. This is supported by the research of [23] which shows that the more ripe the bananas, the higher the percentage of free glucose levels in bananas. Glucose levels here can result in inhibition of LAB growth which acts as a producer of sour taste.
According to [41], high glucose can cause bacterial inhibition because high glucose concentrations can cause low water activity resulting in an increase in osmotic pressure. High osmotic pressure causes hypertonic environmental conditions so that cells become dehydrated and cell death occurs. So that the acid content produced by LAB will reduce the acid content contained in goat's milk kefir, so that the total lactic acid produced will also decrease along with the increase in the maturity level of "Bile" bananas.

The results showed that all treatments did not meet the requirements of SNI yogurt 2981:2009 with total acid ranging from $0.5-2 \%$. This is because the total titrated acid in kefir has increased due to the addition of a prebiotic source in the form of "Bile"banana. [19] said that the acid content in yogurt increased rapidly with the addition of prebiotic sources.

\section{4. $p H$}

Treatment level of ripe "Bile" banana gave a significantly different effect on the $\mathrm{pH}$ of goat's milk kefir. The graph of the relationship between the addition of "Bile" bananas based on the level of maturity to $\mathrm{pH}$ can be seen in Figure 4.

Figure 4 shows that the degree of acidity $(\mathrm{pH})$ of goat's milk kefir with the addition of banana "Bile" puree gives the result that the $\mathrm{pH}$ value increases as the ripeness level of "Bile" banana increases. The increase in $\mathrm{pH}$ value along with the increase in maturity level of "Bile" bananas was due to lactic acid bacteria growing well with the addition of "Bile" banana puree as a natural source of prebiotics for growth media so that higher prebiotics resulted in lower $\mathrm{pH}$ values. The ability of lactic acid bacteria in the fermentation process is able to hydrolysed types of sugar, so that the growth of these bacteria in goat milk kefir can lower the $\mathrm{pH}$. During the fermentation process, lactic acid bacteria will produce lactic acid, citric acid, and acetic acid which will cause the $\mathrm{pH}$ of goat milk kefir to decrease [42]. The degree of acidity is related to total lactic acid, where the lower the resulting $\mathrm{pH}$ value, the higher the lactic acid value [43]. This is in line with the results of the study which showed that the $\mathrm{pH}$ value increased along with the decrease in the total titrated acid value. This is in line with previous research by [44] where symbiotic drinks with the addition of banana puree have a $\mathrm{pH}$ value that is inversely proportional to the total titrated acid value. The increase in $\mathrm{pH}$ occurs as a result of the accumulation of $\mathrm{H}^{+}$ions from lactic acid produced by the metabolism of lactic acid bacteria during fermentation, where the more lactic acid during the fermentation process will result in a decrease in $\mathrm{pH}$ [38]

The degree of acidity $(\mathrm{pH})$ of kefir is generally around 4.6 [45]. Based on the results of the study, it was shown that the treatment that almost met the requirements was the level of maturity level of the chocolate "Bile" banana 
with a value of 4.69. Meanwhile, for the treatment of green, yellowish green, yellow and spotted banana ripeness levels, it did not meet the requirements because it had a $\mathrm{pH}$ value lower than 4.6. This is because the source of prebiotics in "Bile" bananas added to goat's milk kefir increases along with the decrease in the level of banana maturity [18].

\subsection{Viscosity}

The viscosity of goat's milk kefir was measured by viscosity test using a Brookfield Viscometer. Furthermore, it was found that the maturity level of "Bile" bananas had a significantly different effect on the viscosity of goat's milk kefir. The graph of the relationship between the addition of "Bile" bananas based on the level of maturity to viscosity can be seen in Figure 5 .

Figure 5 shows that the higher the level of ripe banana "Bile" added to goat's milk kefir, the lower the viscosity produced. The decrease in the viscosity value of goat's milk kefir is due to the more ripe or ripe the fruit, the higher the water content formed due to the conversion of starch into sugar [18]. In addition, the decrease in the viscosity value of goat's milk kefir is influenced by fermentation activity and the growth of microorganisms. The increase in fermentation activity and the growth of microorganisms will affect the increase in the viscosity of the resulting product [46]. This is due to the presence of Lactobacilli in kefir grains which can increase the viscosity of kefir. Where the activity of Lactobacilli on kefir grains will increase along with increasing sources of prebiotics in kefir which causes the higher level of maturity of "Bile" bananas, the activity of Lactobacilli on kefir in increasing viscosity will decrease [47]. In this case Lactobacilli will produce acid so that there is a decrease in the degree of acidity $(\mathrm{pH})$ in goat milk kefir. A low degree of acidity $(\mathrm{pH})$ will coagulate proteins to form curds, so that probiotic drinks will thicken or their viscosity will be higher [48]. The results showed that the resulting viscosity value was $35,250 \mathrm{cP}-127,250 \mathrm{cP}$ which is the appearance of a thick liquid - solid so that it meets the requirements of yogurt based on SNI 2981:2009.

\subsection{Aroma}

The treatment of the ripeness level of "Bile" bananas did not have a significant effect on the scoring and hedonic tests for the aroma of goat's milk kefir, which can be seen in Figure 6.

Figure 6 shows that the scoring test of goat's milk kefir aroma obtained from various treatments of "Bile " banana maturity level with a value of 2.7-3.15 with the criterion of "slightly flavored prengus". Meanwhile, the hedonic test for goat's milk kefir produces a value of 2.83.1 with the criteria of "rather like ". The reduced aroma

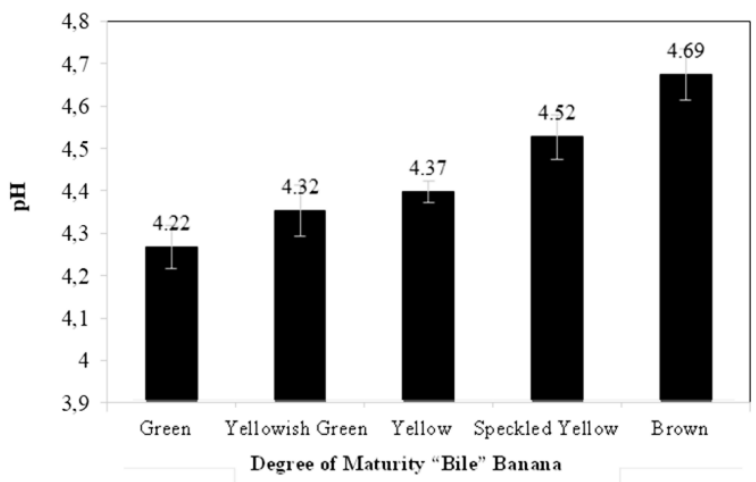

Figure 4 Graph of the Effect of "Bile" Banana Maturity Level on the $\mathrm{pH}$ of Goat Milk Kefir

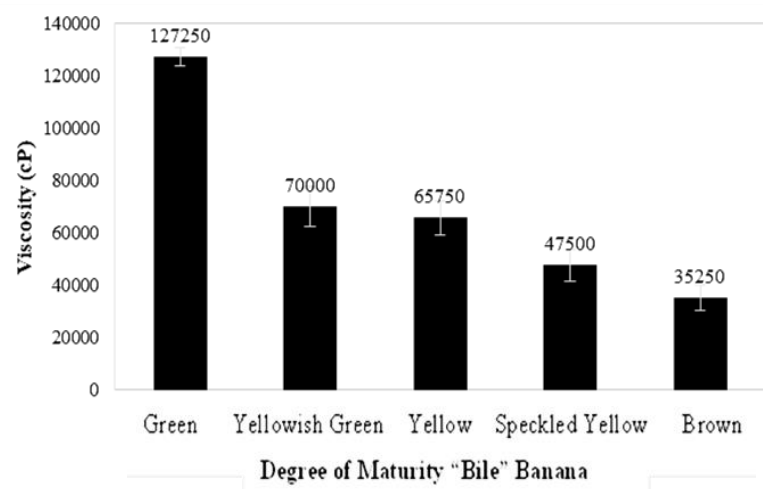

Figure 5 Graph of the Effect of Ripe "Bile” Bananas on the Viscosity of Goat Milk Kefir

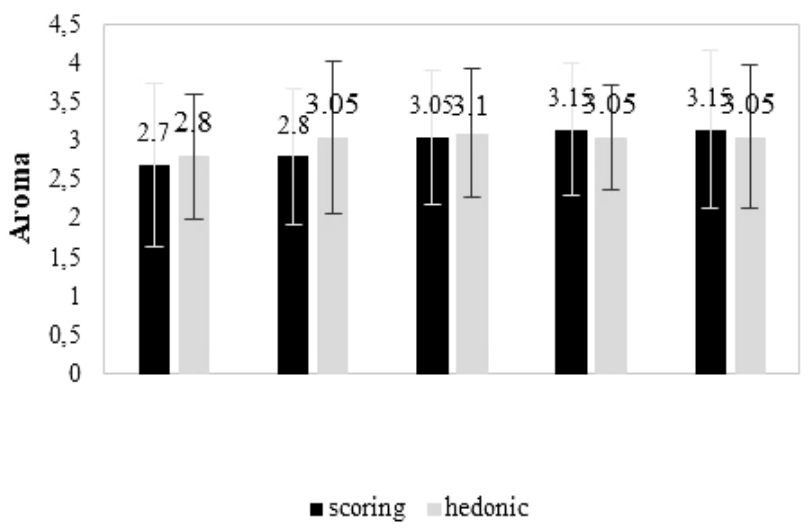

Figure 6 Graph of the Effect of "Bile" Banana Maturity Level on the Aroma of Goat Milk Kefir

of "prengus" in goat's milk is caused by the fermentation process of goat's milk kefir and the addition of goat's milk puree. The sour smell in goat's milk can be reduced due to the fermentation process in goat's milk kefir which suppresses gases or volatile compounds such as acetyl dehide, diacetyl and $\mathrm{CO}_{2}$ [49]. This is supported by the statement of [50] who said that the original aroma of milk will decrease if the acetaldehyde content is high. In this 
case the "Bile" banana acts as a source of prebiotics, namely as a source of nutrition for probiotics in the goat's milk fermentation process and causes an increase in lactic acid bacteria where lactic acid bacteria also play a role in reducing the smell of sour goat's milk. This is in accordance with the statement of [51] who said that the smell of prune can be minimized by the fermentation process of goat's milk where lactic acid bacteria will produce lactic acid so that it can produce a sour aroma.

The decrease in the aroma of prune in goat milk kefir is directly proportional to the increase in panelists' preference for the aroma of goat milk kefir. This is because people do not like the smell of "prengus" in goat's milk [49]. So that the reduced aroma of "prengus" in goat milk causes an increase in preference by the panelists. Kefir generally has an alcoholic aroma caused by yeast activity. However, based on the results of the study, all treatments still produced a prune aroma. So that all treatments have not achieved the best characteristics of goat milk kefir. [52] said that the sensory properties of fermented milk products, especially kefir, were influenced by the type of milk, starter culture and storage period.

\subsection{Taste}

The treatment of the ripeness level of "Bile" bananas did not give a significantly different effect on the scoring test and the hedonic test for the taste of goat's milk kefir which can be seen in Figure 7.

Figure 7 shows that the taste scoring test for goat's milk kefir obtained from various treatments of "Bile" banana maturity level resulted in a score of 4.2-2.9 with the criteria of "sour taste" to "slightly sour taste". The higher the maturity level of the "Bile" banana, the less sour taste in goat's milk kefir. This is due to the sour taste produced by fermentation of lactic acid bacteria whose growth is stimulated by the presence of prebiotics in "Bile" bananas [9]. So that along with the addition of banana "Bile" puree which is getting more raw, it will produce a higher sour taste. According to [22] when fermentation takes place, organic acids will form and additional activity from LAB will produce a higher sour taste. Therefore, the lower the $\mathrm{pH}$ of the goat's milk kefir sample, the panelists will feel the more sour taste of kefir. Another factor that causes a decrease in sour taste in goat's milk kefir along with the increase in ripeness of "Bile" bananas is the acid content contained in "Bile" banana puree. Unripe "Bile" bananas have a more sour taste than green "Bile" bananas. This is in line with research from [53] that the content of unripe bananas has an acidic sensation due to the absence of sugar produced by starch hydrolysis during the fruit ripening process, the sour taste formed due to the adhesive sap mucus produced by banana starch.
The increase in glucose levels in "Bile" bananas along with the increase in maturity causes the starch content which is a prebiotic candidate to decrease [34]. This causes LAB activity to decrease because prebiotics which are nutrients for $\mathrm{LAB}$ in ripe bananas will decrease, where LAB plays an important role in producing a sour taste [19]. The reduced activity of LAB causes the sour taste to be reduced. So that the panelists' preference level increased along with the increase in ripeness of "Bile" bananas added to goat's milk kefir. The results showed that all treatments had a sour taste and had met the requirements for the taste of kefir based on SNI 7552:2009, which was sour/typical of goat's milk kefir.

\subsection{Colour}

The treatment of "Bile" banana maturity level did not give a significantly different effect on the scoring test and the hedonic test for the colour of goat's milk kefir which can be seen in Figure 8 .

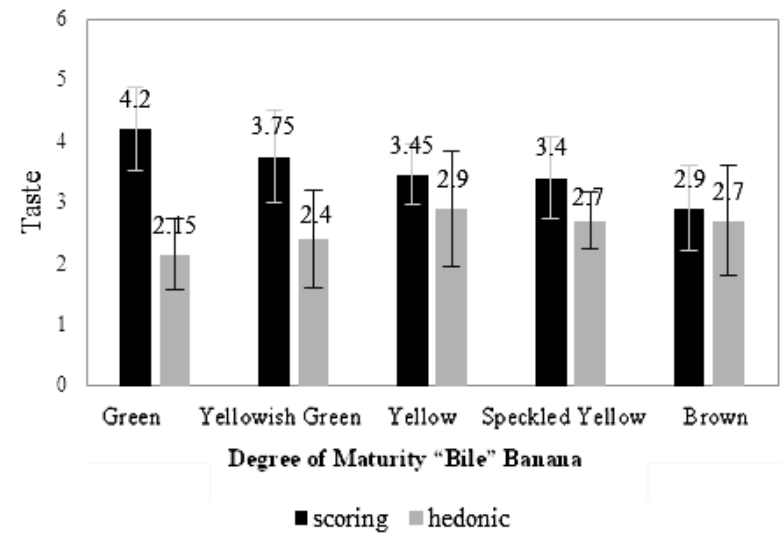

Figure 7 Graph of the Effect of "Bile" Banana Maturity Level on the Taste of Goat Milk Kefir by Scoring and Hedonic

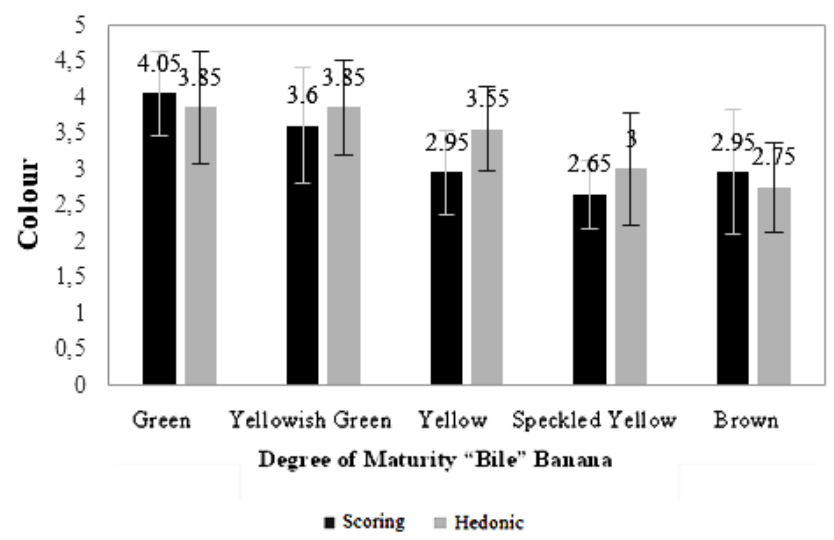

Figure 8 Graph of the Effect of "Bile" Banana Maturity Level on Goat Milk Kefir Color by Scoring and Hedonic 
Figure 8 shows that the color scoring test for goat's milk kefir obtained from various treatments of "Bile" banana maturity level resulted in a value of 4.05-2.65 with the criteria of "yellowish white" to "light yellow".

The color change that occurred along with the increasing maturity level of "Bile" bananas was caused by the addition of "Bile" banana puree. This is due to the presence of carotenoids which are yellow pigments in bananas which will increase as the banana ripens [54]. So that the whiter the colour of goat's milk kefir causes the panelists' preference level to increase.

\subsection{Viscosity Sensory}

The treatment of "Bile" banana maturity level did not give a significantly different effect on the scoring test and the hedonic test of goat milk kefir viscosity which can be seen in Figure 9.

Figure 9 shows that the viscosity scoring test of goat's milk kefir obtained from various treatments of "Bile" banana maturity level resulted in a value of 4.45-3.2 with the criteria of "thick" to "slightly thick". The viscosity of goat's milk kefir which decreases with increasing maturity level of "Bile" bananas is influenced by the level of water content of "Bile" banana puree added to goat's milk kefir. The rawer the banana is, the less the water content in the banana will be [23]. Thus, the banana "Bile" puree added to goat's milk kefir will become thicker as the ripeness level of the "Bile" banana decreases. This is in accordance with previous research by [55] which shows that the ripeness of bananas affects the viscosity of the resulting puree where the rawer the banana, the thicker the puree produced. The panelist's highest preference value was found in the treatment of the spotted yellow maturity level. This shows that the panelists really like the texture that is not too thick. The results showed that all treatments were viscous and had met the requirements for the appearance of yogurt based on SNI 2981:2009, namely the appearance of a thick/solid liquid.

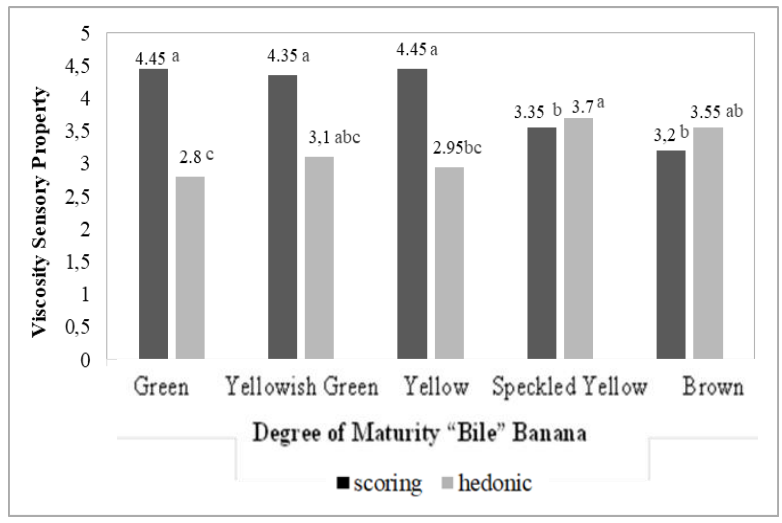

Figure 9 Graph of the Effect of "Bile” Banana Maturity Level on Goat Milk Kefir Viscosity by Scoring and Hedonic

\section{CONCLUSION}

The best results among all treatment was found in the treatment of yellow "Bile" banana maturity level based on the $\mathrm{pH}$ value of 4.37 ; total acid number $4.68 \%$; viscosity $65.750 \mathrm{cP}$; growth of LAB $8.48 \mathrm{log} \mathrm{CFU} / \mathrm{ml}$ and decreased LAB viability $0.47 \log \mathrm{CFU} / \mathrm{ml}$ as well as the scoring and hedonic sensory properties received by the panelists.

\section{REFERENCES}

[1] N. Budiana and D. Susanto, Susu Kambing, Jakarta: Penebar Swadaya, 2005.

[2] A. Sodiq and A. Z., Meningkatkan Produksi Susu Kambing Peranakan Etawa., Jakarta: AgroMedia Pustaka, 2008.

[3] A. Ribeiro and S. D. A. Ribeiro, "'Specialty Products Made from Goat Milk"," Small Ruminant Research, 225-233.

[4] R. L. Balia, H. Chairunnisa., O. Rachmawan and E. Wulandari, "Derajat keasaman dan karakteristik organoleptik produk fermentasi susu kambing dengan penambahan sari kurma yang diinokulasikan berbagai kombinasi starter bakteri asam laktat," Jurnal Ilmu, 2011.

[5] E. Siswanto, "Pembuatan Minuman Kefir Dari Susu Kacang Merah dengan Menggunakan Kultur Starter Lactobacillus bulgaricus dan Saccharomyces cereviceae: Kajian Pengaruh Konsentrasi Starter dan Lama Inkubasi," Fakultas Teknologi Pertanian Untag, 2007.

[6] L. S. A., N. L. P. Sriyani., M. Hartawan and I. G. Suranjaya, "Study mikrobiologis kefir dengan waktu simpan berbeda," Majalah Ilmiah Peternakan, pp. 95-99, 2015.

[7] L. L.A. and S. Helmyati, "Peran Probiotik di Bidang Gizi dan Kesehatan," UGM Press, Yogyakarta, 2018.

[8] R. Edward and Farnworth, "Kefir a complex probiotic.," Food Science and Technology Bulletin, pp. 1-17, 2005.

[9] M. Roberfroid, " Prebiotic : The Concept Revisited," The Journal of Nutrition, pp. 830-837, 2007.

[10] P. Ide, Health Secret Of Kefirl, Yogyakarta: Elex Media Komputindo, 2008.

[11] R. P. Praja, "Pati Resisten dan Sifat Fungsional Tepung Pisang Tanduk (Musa paradisiaca formatypica) yang Dimodifikasi Melalui Fermentasi 
Bakteri Asam Laktat dan Pemanasan Otoklaf," Institut Pertanian Bogor, Bogor, 2010.

[12] Kusharto and M. Clara, "Serat Makanan dan Perannya Bagi Kesehatan," Jurnal Gizi dan Pangan, pp. 45-54., 2006.

[13] R. Hardisari and N. Amaliawati, "Manfaat Prebiotik Tepung Pisang Kepok (Musa paradisiaca formatypica) terhadap Pertumbuhan Probiotik Lactobacillus casei secara In Vitro," Jurnal Tekno Lab, pp. 64-67, 2016.

[14] M. Istianto, "Pisang "Bile", pisang khas asal Nusa Tenggara Barat," 11 May 2015. [Online]. Available: http://balitbu.litbang.pertanian.go.id/index.php/beri ta mainmenu26/13-info-aktual/748-pisang-"Bile"pisangkhas-asal-nusa-tenggara-barat.

[15] M. Soltani, R. Alimardani and M. Omid, "Prediction of banana quality during ripening stage using capacitance sensing system," Australian Journal of Crop Science, pp. 443-447, 2010.

[16] M. Sari and L. Sulandri, "Pengaruh jumlah asam sitrar dan agar-agar terhadap sifat organoleptic manisan bergula puree labu siam," Jurnal tata boga, pp. 100-110., 2014.

[17] FAO, 2020 June 2007. [Online]. Available: http://www.fao.org/ag/agn/agns/files/Prebiotics TechMeetingReport.pdf..

[18] W. Harefa and U. Pato, "Evaluasi Tingkat Kematangan Buah Terhadap," Jurnal FAPERTA, pp. 1-12., 2017.

[19] E. Purwijantiningsih, "Pengaruh Jenis Prebiotik terhadap Kualitas Yogurt Probiotik," Jurnal Biota, pp. 177-185, 2007.

[20] Ferawati, " Formulasi Dan Pembuatan Banana Bars Berbahan Dasar Tepung Kedelai, Terigu, Singkong, dan Pisang Sebagai Alternatif Pangan Darurat," IPB, Bogor, 2009.

[21] R. E. Utami, A. Nurhartadi, M. Nursiwi, Andriani and I. Fitriyaningsih, "Fermentasi Whey Keju Menggunakan Biji Kefir (Kefir Grains) dengan Variasi Sumber Nitrogen," AGRITECH., pp. 337385., 2017.

[22] A. M. Rizky and E. Zubaidah, "Pengaruh penambahan tepung ubi ungu jepang (Ipomea batatas) terhadap sifat fisik, kimia, dan organoleptikkefir ubi ungu," Jurnal Pangan dan Agroindustri, pp. 1393-1404, 2015.

[23] W. Abe, S. Wahyuni and Muzuni, "Pengaruh Tingkat Kematangan Beberapa Jenis Pisang Terhadap Kadar Dekstrin, Nilai Gizi Dan
Organoleptik Tepung Pisang," Jurnal Sains dan Teknologi Pangan, pp. 811-820, 2017.

[24] T. Y. Astuti, L. Agustina and T. Setyawardani, "Penggunaan Starter Biji Kefir Dengan Konsentrasi Yang Berbeda Pada Susu Sapi Terhadap pH Dan Kadar Asam Laktat," Jurnal Ilmiah Peternakan., p. $1,2013$.

[25] T. B. Ramadhani, Nurwantoro and A. Hintono, "Karakteristik Yoghurt dengan Penambahan Tepung Ubi Jalar Ungu," Jurnal Teknologi Pangan, pp. 183- 190. , 2018.

[26] L. Febriyanti and J. Kusnadi, "Pengaruh Penambahan Tepung Kulit Pisang Terhadap Pertumbuhan Bakteri Lactobacillus casei Pada Es Krim Probiotik," Jurnal Pangan dan Agroindustri, pp. 1694-1700, 2015.

[27] D. Martharini and I. Indratiningsih, "Kualitas Mikrobiologis dan Kimiawi Kefir Susu Kambing dengan Penambahan Lactobacillus acidophilus FNCC 0051 dan Tepung Kulit Pisang Kepok (Musa Paradisiaca).," Jurnal AGRITECH, pp. 22-29., 2017.

[28] A. Putra, "Aplikasi pemberian probiotik, prebiotik dan sinbiotik untuk meningkatkan kecernaan pakan ikan nila Oreochromis niloticus," Institut Pertanian Bogor, Bogor, 2010.

[29] M. Eamonn, Quigley and Q. Rodrigo, "Small Intestinal Bacterial Overgrowth: Roles of Antibiotics, Prebiotics, probiotics," Gastroenterology journal, pp. 78-90, 2006.

[30] P. Biggs, C. Parsons and G. Fahey, "The effects of several oligosaccharides on growth performance, nutrient digesbilities, and cecal microbial populations in your chicks," Poultry Science, pp. 2327-2336, 2007.

[31] I. Yogeswara, I. Kusumawati and N. Nursini, "Viabilitas dan Stabilitas Bakteri Probiotik L. acidophillus FNCC 0051 pada Susu Kedelai Fermentasi Selama di Saluran Cerna in Vitro dan Penyimpanan," in Prosiding Seminar Nasional, 2014.

[32] J K. Moustafa, N. Dabour, E. Khead and I. Fliss, " Viability of probiotic bacteria in maple sap products

[33] R. Setiarto, N. Widhyastuti, I. Saskiawan and R. Safitri, "Pengaruh Variasi Konsentrasi Inulin Pada Proses Fermentasi Oleh Lactobacillus Acidophilus, Lactobacillus Bulgaricus Dan Streptococcus Thermophilus. 8 (1) :," Jurnal BIOPROPAL INDUSTRI, pp. 1-17, 2017. 
[34] Satuhu, Suyanti and A. Supriyadi, Pisang: Budi Daya, Pengolahan dan Prospek Dasar, Depok: Penebar Swadaya, 2008.

[31] I. Yogeswara, I. Kusumawati and N. Nursini, "Viabilitas dan Stabilitas Bakteri Probiotik L. acidophillus FNCC 0051 pada Susu Kedelai Fermentasi Selama di Saluran Cerna in Vitro dan Penyimpanan," in Prosiding Seminar Nasional, 2014.

[32] J K. Moustafa, N. Dabour, E. Khead and I. Fliss, " Viability of probiotic bacteria in maple sap products

[33] R. Setiarto, N. Widhyastuti, I. Saskiawan and R. Safitri, "Pengaruh Variasi Konsentrasi Inulin Pada Proses Fermentasi Oleh Lactobacillus Acidophilus, Lactobacillus Bulgaricus Dan Streptococcus Thermophilus. 8 (1) :," Jurnal BIOPROPAL INDUSTRI, pp. 1-17, 2017.

[34] Satuhu, Suyanti and A. Supriyadi, Pisang: Budi Daya, Pengolahan dan Prospek Dasar, Depok: Penebar Swadaya, 2008.

[35] I M. G. Sajilata, R. S. Singhal and P. R. Kulkarni, "Resistant Starch-a Review: Comprehensive Reviews in Food Scienceand Food Safety," Institute of Food Technologists, 2006.

[36] E. Herawati and P. Aditiawati, "Uji Ketahanan terhadap pH Asam dan Garam Empedu pada Bakteri Indigenous Buah Kawista (Feronia limonia) sebagai Kandidat Bakteri Probiotik. Prosiding," in Semnas Hayati IV, Kediri, 2016.

[37] S. Boeni, R. Purahmad and H. Adeli, "Investigation of Viability of Probiotic Bacteria And Physicochemical Characteristics of Synbiotic Yoghurt During Cold Storage," International Journal of Biology and Biotechnology, pp. 359-365, 2012.

[38] S. Salminen, A.V.Wright and A.Ouwehand, Lactic Acid Bacteria: Microbiology and Functional, New York: Marcel Dekker Inc., 2004.

[39] A. U. Prastujati, M. Hilmi and M. H. Khirzin, "Pengaruh Konsentrasi Starter terhadap Kadar Alkohol, pH, dan Total Asam Tertitrasi (TAT) Whey Kefir," Jurnal Imu Peternakan Terapan, pp. 63-69, 2018.

[40] Purwiyanto and Hariyadi, "Southest Asian Food and Agricultural Science an Technology (SEAFAST)," 2005.

[41] J. Chirife, L. Herszage, A. Joseph and E. S. Kohn, "In Vitro Study of Bacterial Growth Inhibition in Concentrated Sugar Solutions: Microbiological Basis for the Use of Sugar in Treating Infected
Wounds," Journal Antimicrobial Agents and Chemotherapy, pp. 766-773, 1983.

[42] I. Surono, Probiotic Susu Fermentasi dan Kesehatan, Jakarta: Yayasan Pengusaha Makanan dan Minuman Seluruh Indonesia, 2004.

[43] R. Nofrianti, F. Azima and R. Eliyasmi, "Pengaruh Penambahan Madu terhadap Mutu Yoghurt Jagung," Jurnal Aplikasi Teknologi Pangan, pp. 6067, 2013.

[44] D. Denilasari and N. Lestari, "Formulasi Minuman Sinbiotik Dengan Penambahan Puree Pisang Ambon (Musa paradisiaca var sapientum) dan Inulin Menggunakan Inokulum Lactobacillus casei," AGRITECH, pp. 257-265, 2014.

[45] A. Rahman, S. Fardiaz, W. P. Rahayu, Suliantari and C. C. Nurwitri, "Teknologi Fermentasi Susu. Pusat Antar Universitas Pangan dan Gizi," Institut Pertanian Bogor, Bogor, 1992.

[46] I H. Evanuarini, "Pengaruh Suhu dan Lama Pemeraman Pada Inkubator Terhadap Kualitas Fisik Kefir," Jurnal Ilmu-ilmu Peternakan, pp. 8-13, 2010.

[47] L. Lestari and S. Helmyati, "Peran Probiotik di Bidang Gizi dan Kesehatan," UGM Press, Yogyakarta, 2018.

[48] N. Aini, V. Prihananto, G. Wijonarko, A. Arimah and M. Syaifudin, "Pengaruh Konsentrasi Kultur dan Prebiotik Ubi Jalar terhadap Sifat Sari Jagung Manis Probiotik," Jurnal Agritech, pp. 165-172, 2017.

[49] N. Fidina, N. E. Sukarminah and D. M. Sumanti, "The Effects of the Addition of Banana Puree to the Total Number of Total Probiotic Bacteria, $\mathrm{pH}$ Value and Organoleptic Characteristics of the Synbiotic Yogurt Made from Goat Milk and Banana Puree," Journal of Industrial and Information Technology in Agriculture, pp. 12-21, 2018.

[50] G. Rysstad and R. Abrahamsen, "Formation of Volatile Aroma Compounds and Carbondioxyde in Yoghurt Starter Grown in Cow's Milk and Goat Milk," J. Dairy Res., pp. 257-266, 2000.

[47] L. Lestari and S. Helmyati, "Peran Probiotik di Bidang Gizi dan Kesehatan," UGM Press, Yogyakarta, 2018.

[48] N. Aini, V. Prihananto, G. Wijonarko, A. Arimah and M. Syaifudin, "Pengaruh Konsentrasi Kultur dan Prebiotik Ubi Jalar terhadap Sifat Sari Jagung Manis Probiotik," Jurnal Agritech, pp. 165-172, 2017.

[49] N. Fidina, N. E. Sukarminah and D. M. Sumanti, "The Effects of the Addition of Banana Puree to the 
Total Number of Total Probiotic Bacteria, $\mathrm{pH}$ Value and Organoleptic Characteristics of the Synbiotic Yogurt Made from Goat Milk and Banana Puree," Journal of Industrial and Information Technology in Agriculture, pp. 12-21, 2018.

[50] G. Rysstad and R. Abrahamsen, "Formation of Volatile Aroma Compounds and Carbondioxyde in Yoghurt Starter Grown in Cow's Milk and Goat Milk," J. Dairy Res., pp. 257-266, 2000.

[51] J. Djuedjevic, O. Macej and S. Jovanic, ", 2002. The influence of investigated factors on viscosity of stirred yogurt," Journal of Agriculture Sciences, pp. 219-231, 2002.

[52] A. Y. Wszolek, Tamime, D. Muir and M. Barclay, "Properties of kefir made in Scotland dan Poland Using Bovine, Caprine and Ovine Milk With Different Starter Culture," LWT-Food Science and Technology, pp. 251-261, 2001.

[53] O. Miftah, Karakteristik Buah Pisang Lokal yang Terdapat di Indonesia, Jakarta: PT. Gramedia, 2015. under storage and gastrointestinal conditions," Bioresource Technology, p. 7966 - 7972, 2010.

[54]. Lawalata and G. Tetelepta, "Daya Terima Minuman Sari Buah Pisang Tongka Langit dengan Perlakuan Lama Blansing," Jurnal Teknologi Pertanian, pp. 24-28, 2019.

[55] M. Yap, W. Fernando, C. Brenna, V. Jayasena and R. Coorey, "The effects of banana ripeness on quality indices for puree production," Food Science and Technology Journal, pp. 10-18, 2017.

[56] T. Y. Astuti, L. Agustina and T. Setyawardani, "Penggunaan Starter Biji Kefir Dengan Konsentrasi Yang Berbeda Pada Susu Sapi Terhadap pH Dan Kadar Asam Laktat.," Jurnal Ilmiah Peternakan, p. 1, 2013.

[57] . I. Yogeswara, I. Kusumawati and N.W. Nursini, "Viabilitas dan Stabilitas Bakteri Probiotik L. acidophillus FNCC 0051 pada Susu KedelaiFermentasi," 2014. 